k.banaszewski@bu.uz.zgora.pl

Katarzyna Bartosiak

k.bartosiak@bu.uz.zgora.pl

Biblioteka Uniwersytetu Zielonogórskiego

\title{
PRZEGONIĆ CHMURY: KOMUNIKOWANIE WIZJI, MISJI I WARTOŚCI NA STRONACH WWW BIBLIOTEK AKADEMICKICH
}

\begin{abstract}
There are many uncertains about the future of academic libraries in contemporary debates. Dictated with changes in the environment as well as in education, they make the redefinition of university libraries necessary and the new formula for their identity is needed. Answers for following about mission and vision of libraries should be found: how do libraries see their future and their prospective role? could library image be shaped by mission and vision, plans and strategies, values and goals? could those affect the stakeholders' evaluation? If so, whether and how are they communicated to the users? Do academic libraries use the communication and information potential of their own websites? Analyzing the web pages of the Polish public university libraries, the article examines whether and where the information about the mission, vision and values is placed on their web portals.
\end{abstract}

Słowa kluczowe: biblioteki akademickie, misja i wizja biblioteki, strony WWW bibliotek

\section{Wstęp}

Rola i zadania bibliotek akademickich coraz częściej stawiane są pod znakiem zapytania i rozważane w kontekście niejasnej przyszłości. Czy jest tak, że tradycyjne funkcje książnic uczelnianych okazują się niewystarczające dla współczesnych użytkowników, czy raczej to sposoby realizacji owych powinności wydają się anachroniczne? Czy wartości, jakim od lat hołdują biblioteki, odpowiadają nowym wymogom i potrzebom interesariuszy, czy też może bibliotekarze wiedzą lepiej i wciąż oferują usługi, które z punktu widzenia odbiorcy nie są atrakcyjne, a być może nawet zbyteczne? Czy biblioteki uczelniane dbają o własny rozwój i zastanawiają się nad kierunkiem, w jakim należy podążać? Idą z duchem czasów, czy raczej starają się go dogonić? 
Zmiany zachodzące w otoczeniu książnic akademickich, obejmujące zarówno nowe przedsięwzięcia i zadania uczelni wyższych, bezsprzeczną konkurencyjność Internetu jako źródła informacji i wiedzy, aktualne trendy we współczesnej edukacji, nowy typ użytkownika, będącego często przykładem cyfrowego tubylcy, który świetnie orientuje się w świecie nowoczesnych technologii, czy wreszcie same te technologie i ich wpływ na usługi biblioteczne, pozwalają żywić obawy, że nad bibliotekami uczelnianymi zawisły czarne chmury. Jak twierdzi wręcz Binh P. Le, „biblioteki akademickie... przechodzą egzystencjalny kryzys. Samo ich istnienie jest zagrożone"1. Jeśli nawet przyjać, że sytuacja nie przedstawia się tak ostatecznie, to jednak pod uwagę należy wziąć fakt, że wiele bibliotek uczelnianych cechuje znaczne opóźnienie w adaptacji do nowych okoliczności. Jak podpowiada Louise McGillis, „chociaż [...] odpowiadamy na zachodzące dookoła nas zmiany i robimy nowe rzeczy, to jednak jeśli w tych pełnych wyzwań czasach chcemy posiadać znaczącą rolę, musimy wymagać od siebie dużo więcej”2. Transformacje bibliotek i nowe podejście do samych podstaw ich funkcjonowania i przyszłego rozwoju wydają się więc nie tylko nieuniknione, ale wręcz konieczne. Równie ważne staje się budowanie nowej tożsamości bibliotek, ich rozpoznawalności w środowiskach uczelnianych, tworzenie ich nowoczesnego wizerunku, bardziej pasującego do upodobań i wymogów dzisiejszych użytkowników. „Porzucenie starych sposobów działania na rzecz nowych misji [...] może sprzyjać transformacyjnym zmianom w bibliotekach"3, a formułowanie nowych wizji, zdefiniowanie nowych wartości, celów, strategii działania i rozwoju - umocnić ich pozycję w środowisku akademickim i być może wyznaczyć im rolę nie tylko przewodników, ale i inicjatorów w świecie nauki.

${ }^{1}$ B.P. Le, Academic library leadership in the digital age, „Library Management” 2015, vol. 36, issue 4/5, s. 312, http://www.emeraldinsight.com/doi/full/10.1108/LM-07-2014-0083 [dostęp: 09.04.2017].

${ }^{2}$ L. McGillis, The lights are on but nobody's home: the future of academic libraries?, „Partnership: The Canadian Journal of Library and Information Practice and Research” 2016, vol. 11, no 1, s. 4, https://journal.lib.uoguelph.ca/index.php/perj/articleview/3657/3755\#.WO oBU_mLTIV, [dostęp: 09.04.2017].

${ }^{3}$ J.J. Meier, The Future of Academic Libraries: Conversations with Today's Leaders about Tomorrow, „Portal: Libraries and the Academy” 2016, vol. 16, no 2, s. 264, http:// search.proquest.com/docview/1784465065/fulltextPDF/A711FB8C40A84B2CPQ/1?accountid= 14686, [dostęp: 09.04.2017]. 


\section{Misja, wizja, strategia}

Misja, wizja i strategia to pojęcia mające swój rodowód w naukach o zarządzaniu. Związane często $\mathrm{z}$ marketingiem i działaniami promocyjnymi współczesnych organizacji, dokumenty te nie są obowiązkowe, jednak - informując interesariuszy na temat celów, planów, wartości, atutów - budują tożsamość organizacji oraz stanowią „doskonałe narzędzie komunikacji na zewnątrz, jak i wewnątrz firmy"4. Wizja to określenie długookresowych celów organizacji, marzenie kierownictwa na temat wizerunku firmy w przyszłości, „Wielki, Ambitny i Zuchwały Cel”, stanowiący podstawę, z której „kolejno wynikają: misja firmy, lansowana w niej kultura oraz przyjmowana w niej strategia organizacyjna. Wszystkie wymienione elementy łączy i integruje, odzwierciedlany w nich, jednolity system wartości”" Misja, niekiedy wyrażana w postaci krótkich, chwytliwych haseł, czy sloganów, pozwala organizacji odpowiedzieć na podstawowe pytania dotyczące jej istnienia: kim jesteśmy? Jaka jest nasza rola? Jakim wartościom hołdujemy, jakie promujemy? Dla kogo istniejemy? „Jasna, przemyślana misja daje pracownikom poczucie wspólnego

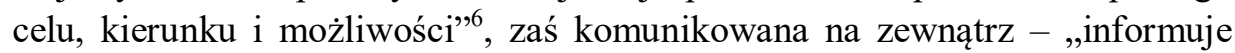
akcjonariuszy, dostawców, klientów o tym, w czym jesteśmy lepsi od innych jako firma i co chcemy dla nich zrobić" "ᄁ. Strategia zaś związana jest z planowaniem działań organizacji, wynikająca z misji organizacji i wspierająca jej kluczowe wartości, stanowi sformułowanie kilkuletnich zamierzeń i celów firmy oraz sposobów ich osiągnięcia ${ }^{8}$.

\section{Problem badawczy. Pytania badawcze}

Świat biblioteczny wydaje się doceniać możliwości związane z kreowaniem nowej tożsamości i wizerunku książnic uczelnianych przy wykorzystaniu podpowiedzi ze strony specjalistów od marketingu i nowoczesnego zarządzania, o czym świadczy bogata literatura przedmiotu. W piśmiennictwie ostatnich lat pojawiło się bowiem wiele pozycji traktujących o tworzeniu, elementach

\footnotetext{
${ }^{4}$ Por. B. Kozyra, Strategiczne zarządzanie firma - Misja i Wizja, czyli nazywanie marzeń, http://www.przepisnabiznes.pl/dzialalnosc-gospodarcza/strategiczne-zarzadzanie-firma.html, [dostęp: 09.04.2017].

${ }^{5}$ S. Chełpa, Zarzadzanie wartościami: wizja - misja - kultura - strategia organizacyjna, „Zarządzanie i Marketing. Prace Naukowe Akademii Ekonomicznej we Wrocławiu” 1998, nr 789, s. 189.

${ }^{6}$ P. Kotler, Marketing, Poznań 2005, s. 91.

${ }^{7}$ B. Kozyra, op. cit.

${ }^{8}$ Por. M. Bielski, Organizacje: istota, struktury, procesy, Łódź 2001, s. 149-150.
} 
składowych, treściach, funkcjach misji i wizji, wartości i strategii w kontekście działalności bibliotecznej. Na gruncie rodzimego bibliotekarstwa również możemy znaleźć odnośną literaturę, począwszy od ogólnych opracowań poświęconych organizacji czy marketingowi bibliotecznemu pióra Jacka Wojciechowskiego $^{9}$ aż po szczegółowe teksty, na przykład Lidii Derfert-Wolf ${ }^{10}$ czy Zdzisława Gębołysia ${ }^{11}$. Za niejako manifest programowy dotyczący budowania misji biblioteki uznać można tekst Piotra Karwasińskiego Misja biblioteki: wyzwanie - cel - zadanie. Próba stworzenia misji Biblioteki Uniwersyteckiej w Poznaniu ${ }^{12}$, w którym autor zaznacza, iż kreowanie misji powinno być nierozerwalnie związane $\mathrm{z}$ informowaniem jej szeroko rozumianemu otocze$\operatorname{niu}^{13}$.

$\mathrm{Z}$ drugiej strony, budowanie i umacnianie wizerunku, tożsamości, promocja, kształtowanie ocen społecznych, informowanie otoczenia o sprawach biblioteki i komunikowanie się z użytkownikami odbywa się dzisiaj w dużej mierze za pośrednictwem bibliotecznych witryn internetowych. Czy portale te są czytelne, nowoczesne, zachęcające do odwiedzin? Czy są dostępne w wersji mobilnej? Czy tworzy się je i aktualizuje zgodnie z zasadami architektury informacji? Zagadnieniu temu poświęcona jest obszerna literatura. Także w polskiej publicystyce bibliotecznej można odnaleźć trend związany z analizą i oceną bibliotecznych serwisów WWW (wspomnijmy tutaj teksty Pauliny Milewskiej $^{14}$, czy Anny Wałek ${ }^{15}$ ).

Jeżeli założymy, że misja, wizja i strategia to dokumenty, stanowiące próbę zmierzenia się biblioteki $\mathrm{z}$ nadchodzącą, niepewną przyszłością oraz przyjmiemy, iż zapisy te powinny być komunikowane użytkownikom (zaś

${ }^{9}$ J. Wojciechowski, Organizacja i zarządzanie w bibliotekach, Kraków 1998; idem; Marketing w bibliotece, Warszawa 1993; idem, Marketing w bibliotece, Warszawa 1993.

${ }^{10}$ L. Derfert-Wolf, Strategia rozwoju biblioteki, [w:] EBIB Elektroniczny Biuletyn Informacyjny Bibliotekarzy. Materiaty konferencyjne, http://www.ebib.pl/publikacje/matkonf/atr/ indexpl.html, [dostęp: 9.04.2017].

${ }^{11}$ Z. Gębołyś, Misja biblioteki naukowej w teorii i praktyce, [w:] Zarządzanie strategiczne i marketingowe w bibliotekach, Poznań 2004, s. 43-50.

${ }^{12}$ P. Karwasiński, Misja biblioteki: wyzwanie - cel - zadanie. Próba stworzenia misji Biblioteki Uniwersyteckiej w Poznaniu, „Biblioteka” 2006, nr 10 (19), s. 129-144.

${ }^{13}$ Ibidem, s. 131.

${ }^{14} \mathrm{P}$. Milewska, Jak odstraszyć czytelnika, czyli strony internetowe bibliotek, „Biuletyn EBIB” 2015, nr 3 (157a), http://open.ebib.pl/ojs/index.php/ebib/article/viewFile/343/508, [dostęp: 9.04.2017]; eadem, Strona $W W W$ biblioteki uczelnianej - kreatywna wizytówka instytucji?, [w:] Kreatywność i innowacje w bibliotece naukowej, red. A. Marciniak, I. Sujkowska, Łódź 2013, s. 105-136, http://cybra.p.lodz.pl/dlibra/docmetadata?id=7810\&from=pubindex\& dirids $=1 \& 1 \mathrm{p}=3201$, [dostęp: 05.04.2017].

${ }^{15}$ A. Wałek, Strony $w w w$ bibliotek jako element promocji i narzędzie komunikacji z użytkownikiem, „Fides. Biuletyn Bibliotek Kościelnych” 2014, nr 1 (38), s. 109-118, http://www. fides.org.pl/pdf/biuletyn/38_109-118.pdf, [dostęp: 9.04.2017]. 
w dzisiejszej bibliotecznej rzeczywistości dziać się to może za pomocą witryny WWW), możemy sformułować następujący problem badawczy: czy i jak biblioteki akademickie wykorzystują informacyjny i komunikacyjny potencjał swoich stron WWW do promocji wśród użytkowników własnych wartości, celów, ról i wizerunku? Czy korzystając z serwisu internetowego biblioteki, użytkownik może się dowiedzieć, jak dana biblioteka postrzega swoją przyszłość i w jakich zadaniach upatruje swoją rolę? Czy strony WWW polskich bibliotek uczelnianych stanowią ich e-wizytówkę, zawierającą informacje na temat misji, wizji, celów i wartości książnicy? Czy i w jakim stopniu można to sprawdzić, analizując portale biblioteczne, niezależnie od treści zawartych w takich zapisach i deklaracjach, jak misja czy wizja?

Tak określony problem nie doczekał się jeszcze wielu opracowań (w polskiej literaturze przedmiotu w ogóle nie był analizowany). Posiłkując się jednak wynikami kilku podobnych badań (choć dotyczących jedynie występowania na bibliotecznych stronach WWW dokumentu misji) ${ }^{16}$ i w dużej mierze wzorując się na stosowanej $\mathrm{w}$ nich metodologii, autorzy spróbują odpowiedzieć na pytanie, w jakim stopniu, w jaki sposób, w jakim miejscu i czy w ogóle misja, wizja, wartości, plany i cele bibliotek akademickich w Polsce są reprezentowane na ich stronach internetowych.

\section{Metodologia badań}

Kwerendą objęto witryny internetowe 59 bibliotek polskich publicznych uczelni akademickich ${ }^{17}$. Dane zbierane były z zachowaniem podziału na typy szkół wyższych (uniwersytety, uczelnie techniczne, ekonomiczne, pedagogiczne, rolnicze/przyrodnicze, wychowania fizycznego i teologiczne). Strony bibliotek uczelnianych przeanalizowano pod kątem obecności oraz lokalizacji

${ }^{16}$ T. Kuchi, Communicating Mission: An Analysis of Academic Library Web Sites, „Journal of Academic Librarianship” 2006, vol. 32, no 2, s. 148-154, http://www.science direct.com/science/article/pii/S0099133305001837, [dostęp: 9.04.2017]; P. Salisbury, M.R. Griffis, Academic Library Mission Statements, Web Sites, and Communicating Purpose, „Journal of Academic Librarianship” 2014, vol. 40, issue 6, s. 592-596 http://www.science direct.com/science/article/pii/S0099133314001839?, [dostęp: 9.04.2017]; M. Stover, Library Web Sites: Mission and Function in the Networked Organization, „Computers in Libraries” 1997, vol. 17, no 10, s. 55-57, http://scholarworks.calstate.edu/bitstream/handle/10211.2/1704/ StoverMark199712.pdf?sequence=1, [dostęp: 9.04.2017].

${ }^{17}$ Według listy uczelni podległych nadzorowi Ministerstwa Nauki i Szkolnictwa Wyższego. Wykaz uczelni publicznych nadzorowanych przez Ministra wtaściwego ds. szkolnictwa wyższego - publiczne uczelnie akademickie, http://www.nauka.gov.pl/uczelnie-publiczne/wykazuczelni-publicznych-nadzorowanych-przez-ministra-wlasciwego-ds-szkolnictwa-wyzszego-pub liczne-uczelnie-akademickie.html, [dostęp: 04.04.2017]. 
informacji dotyczących misji, wizji, hasła misyjnego (sloganu), wartości, celów, zadań, planów i strategii bibliotek. W badaniu nie brano pod uwagę treści ujętych w wymienionych dokumentach i zapisach, a jedynie ich występowanie, położenie i dostęp do nich. Sprawdzono kolejno zawartość stron głównych, zakładek (podstron), pozycji w rozwijanych menu, linków odnośnych, banerów i innych elementów stron. W procesie badawczym używano również wyszukiwarek własnych witryn, jeśli takie istniały.

Poza określeniem obecności (lub braku) na stronie biblioteki informacji na temat misji, wizji, wartości, celów, strategii (planów) i hasła (sloganu), odnotowano także występowanie pokrewnych komunikatów (na przykład wyniki przeprowadzonej przez bibliotekę analizy SWOT). Podczas badania nie ograniczono się jedynie do stwierdzenia występowania powyższych informacji, sprawdzono bowiem także, w jaki sposób i z jakiej perspektywy są one komunikowane na stronie. Ponieważ lokalizacja owych danych w ramach witryny internetowej stanowiła kolejny etap badań, zastosowano podejście nawigacyj$n \mathrm{e}^{18}$. Przede wszystkim zweryfikowano, czy poszukiwane dane umiejscowione są na witrynie domowej biblioteki (widoczne bezpośrednio po wejściu na stronę główną), czy też - aby do nich dotrzeć - trzeba wykonać co najmniej jedno kliknięcie, niejako w głąb strony (informacja dostępna pod linkiem niebezpośrednim). W badaniu skupiono się także na sprawdzeniu, z ilu różnych miejsc na stronie istnieje dostęp do szukanych danych. Sprawdzono też ilość kroków koniecznych w celu dotarcia do którejś z poszukiwanych informacji (ustalono, że odznaczona zostanie ta informacja, do której można dotrzeć najszybciej - czyli na przykład potrzebujemy tylko dwóch kliknięć od strony głównej, by móc zapoznać się z komunikatem bibliotecznej misji), jednak z uwagi na to, iż ilość analizowanych danych była duża, a także w wielu przypadkach ilość dostępów do tych samych danych przekraczała jeden, w trakcie analizy uzyskanych rezultatów zrezygnowano z kolumny ,ilość kliknięć”, gdyż wyniki mogłyby się okazać niekonkluzywne (zbyt wiele zmiennych, do których dotrzeć można na kilka sposobów). Przeanalizowano także te elementy stron bibliotecznych, w których najczęściej pojawiała się wzmianka odnośnie szukanych zapisów misyjnych i podobnych. Elementy witryn, zawierające poszukiwane treści, podzielono umownie na cztery kategorie: O Bibliotece, Informator, Użytkownicy oraz Regulaminy.

\footnotetext{
${ }^{18}$ Podejście nawigacyjne dotyczy badań nad zawartością stron WWW i opiera się na zasadzie, według której „treść strony internetowej ma charakter hierarchiczny, to znaczy, że informacje postrzegane jako ważniejsze czy bardziej znaczące dla wywarcia wrażenia na użytkownikach umieszczane są w bardziej widocznym i łatwiej dostępnym miejscu”. P. Salisbury, M.R. Griffis, op. cit., s. 594.
} 


\section{Wybrane wyniki badań i ich omówienie}

Przedstawione poniżej wyniki to zaledwie część rezultatów uzyskanych w badaniu. $Z$ uwagi na objętość tekstu autorzy zdecydowali się zaprezentować najważniejsze $\mathrm{z}$ nich. I tak, tab. 1 ilustruje, czy i w jakim stopniu biblioteki publicznych uczelni akademickich za pośrednictwem witryn WWW komunikują użytkownikom swoją misję, wizję, wartości, cele, zadania, strategię, slogan lub inny element programowo traktujący o ich bieżących lub planowanych zadaniach.

Link lub odsyłacz do misji na swoich stronach internetowych umieściło 39\% bibliotek objętych kwerendą. To zdecydowanie więcej niż w przypadku drugiego elementu - wizji. Tutaj tylko 3\% placówek zdecydowało się na zaprezentowanie swojej wizji na stronie WWW biblioteki. W trakcie kwerendy w badanej próbie nie dało się wyodrębnić wartości, rozumianych jako część bądź składnik misji - stąd zerowy udział w próbie. Dodatkowego komentarza wymaga umieszczona w tabeli grupa cele i zadania. Trafiały tutaj także cele rozumiane nie jako cele strategiczne, a raczej jako zadania wynikające z samej funkcji biblioteki uczelnianej - najczęściej w formie zadań wymienionych w regulaminie organizacyjnym biblioteki. Stąd w dużej mierze wynika tak częste ich występowanie (64\%) w badanej próbie. Strategia organizacji jako dająca się wyraźnie rozpoznać odrębna część pojawiła się w 8\% analizowanych stron WWW. Slogan rozumiany jako motto czy też hasło misyjne pojawił się tylko w jednym przypadku, co stanowi niecałe $2 \%$ wszystkich przeanalizowanych bibliotecznych stron internetowych. Również ostatni, wymieniony w tab. 1 termin, wymaga doprecyzowania. W kategorii oznaczonej jako Inne znalazły dające się wyraźnie wyodrębnić elementy (uzupełniające), jak chociażby związane z misją i wizją metody i techniki analizy strategicznej organizacji, jak SWOT, a także Kodeks etyki pracowników i Kodeks etyki bibliotekarza i pracownika informacji (czy niepasujący nigdzie indziej zapis, określony w jednej z badanych bibliotek mianem Przyszłość). Takie dodatkowo precyzujące misję techniki zamieściło na swoich witrynach $10 \%$ badanych bibliotek. 
Tabela 1

Statystyka dostępności misji, wizji, wartości, celów, strategii, sloganów lub innych (dokumentów programowych ) na stronach WWW bibliotek

\begin{tabular}{|c|c|c|}
\hline Kategorie & Jest (\%) & Nie (\%) \\
\hline Misja & 39 & 61 \\
\hline Wizja & 3 & 97 \\
\hline Wartości & 0 & 100 \\
\hline Cele/zadania & 64 & 36 \\
\hline Strategia/plan & 8 & 92 \\
\hline Slogan & 2 & 98 \\
\hline Inne & 10 & 90 \\
\hline
\end{tabular}

Źródło: opracowanie własne (n=59).

Uwzględniając poszczególne typy uczelni, wystąpienia interesujących elementów na stronach WWW bibliotek objętych badaniem prezentuje tab. 2 . Najlepiej, jeżeli chodzi o komunikowanie misji użytkownikom, wypadają uczelnie wychowania fizycznego - aż $67 \%$ bibliotek szkół wyższych o tym profilu umieściło na własnej witrynie internetowej taką informację. Również $60 \%$ bibliotek uczelni ekonomicznych komunikuje swoją misję użytkownikom za pośrednictwem własnego serwisu internetowego. Pomijając w tym zestawieniu biblioteki uczelni teologicznych, najrzadziej swoją misję prezentują na własnych portalach książnice uczelni o profilu technicznym (22\%). Wizja pojawia się jedynie na witrynach bibliotek akademickich oraz uczelni o profilu technicznym (w obu wypadkach jest to jedynie 6\%). Cele i zadania placówki to element najczęściej pojawiający się na stronach WWW bibliotek objętych kwerendą, często za sprawą odpowiednich wpisów w regulaminach placówek, nie zaś $\mathrm{w}$ dokumentach zawierających samą misję.

W badaniu analizowano również, czy dostęp do misji, wizji, bądź innych badanych elementów możliwy jest bezpośrednio z poziomu strony głównej (domowej) biblioteki. Przeważająca większość placówek (aż 97\%) zdecydowała się na dostęp za pośrednictwem któregoś z komponentów, przycisków bądź linków na stronie. Najprawdopodobniej wpływ na powyższe rozwiązanie mają takie czynniki, jak ograniczone miejsce, konieczność pomieszczenia dużej ilości istotnych informacji przy zachowaniu ogólnej czytelności i przyjazności strony. 
Tabela 2

Statystyka dostępności misji, wizji, wartości, celów, strategii, sloganów lub innych (dokumentów programowych) na stronach WWW bibliotek

\begin{tabular}{|c|c|c|c|c|c|c|c|}
\hline 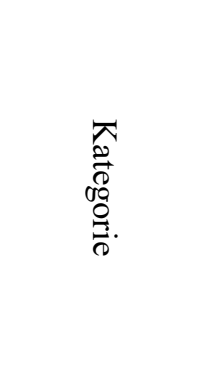 & 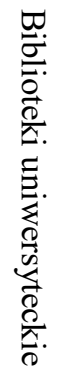 & 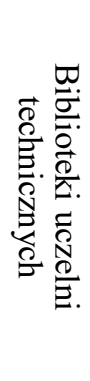 & 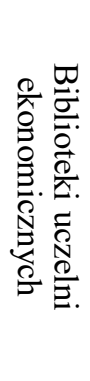 & 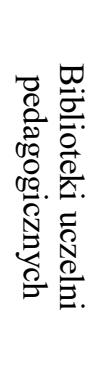 & 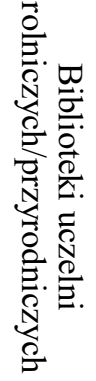 & 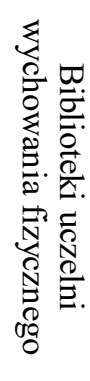 & 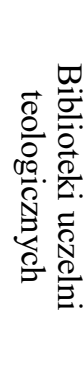 \\
\hline Misja (\%) & 39 & 22 & 60 & 40 & 50 & 67 & 0 \\
\hline Wizja (\%) & 6 & 6 & 0 & 0 & 0 & 0 & 0 \\
\hline Wartości (\%) & 0 & 0 & 0 & 0 & 0 & 0 & 0 \\
\hline $\begin{array}{c}\text { Cele/ } \\
\text { Zadania (\%) }\end{array}$ & 67 & 61 & 60 & 100 & 50 & 50 & 100 \\
\hline $\begin{array}{l}\text { Strategia/ } \\
\text { Plan }(\%)\end{array}$ & 22 & 0 & 0 & 0 & 0 & 17 & 0 \\
\hline Slogan (\%) & 0 & 6 & 0 & 0 & 0 & 0 & 0 \\
\hline Inne $(\%)$ & 17 & 11 & 0 & 20 & 0 & 0 & 0 \\
\hline
\end{tabular}

Źródło: opracowanie własne ( $\mathrm{n}=59)$.

Tabela 3

$\mathrm{Z}$ ilu miejsc na stronie WWW możliwy jest dostęp do badanych elementów?

\begin{tabular}{|c|c|c|c|c|c|c|c|}
\hline \multicolumn{1}{|c|}{ Liczba miejsc dostępu na stronie WWW (\%) } \\
\hline 0 & 1 & 2 & 3 & 4 & 5 & 6 & 7 \\
\hline 37 & 44 & 12 & 3 & 0 & 0 & 2 & 2 \\
\hline
\end{tabular}

Źródło: opracowanie własne ( $\mathrm{n}=59)$. 
Uzyskane wyniki pokazują (tab. 3), że w przypadku bibliotek, które podają swoją misję na stronach WWW za pośrednictwem któregoś komponentu, możemy wskazać kilka dających się wyodrębnić rodzajów linków i odsyłaczy. Choć mają one różne nazwy, generalnie da się je podzielić na cztery kategorie, którym na potrzeby tekstu nadano następujące nazwy: $O$ bibliotece, Informator, Użytkownicy, Regulaminy. $\mathrm{W}$ grupie $\mathrm{O}$ bibliotece znalazły się wszystkie te komponenty, w których instytucje najczęściej umieszczają zwięzłe informacje o sobie, swojej działalności, raporty i sprawozdania z działalności (przykładowo trafiły tutaj linki o nazwach: O nas, Biblioteka, Informacje o Bibliotece, Przyjazna Biblioteka). Drugą grupę (Informator) tworzą te spośród odsyłaczy bądź elementów strony, w których umieszczono różne formy poradników, przewodników ułatwiających poruszanie się po witrynie i systemie bibliotecznym (na przykład Krok po kroku, Informatory, Informacje). Do trzeciej grupy (Użytkownicy) włączono te elementy stron, które zawierały misję lub wizję (a także ich elementy), a odnosiły się do użytkowników w ogóle, bądź do jakiejś konkretnej ich grupy (Studenci, Pracownicy, Użytkownik). Ostatni wyodrębniony zbiór, nazwany zbiorczo Regulaminy, tworzą te spośród odsyłaczy i linków, które odsyłają nawigującego po stronie użytkownika przede wszystkim do różnego rodzaju regulaminów bądź ich części (takich jak: Regulamin, Regulamin biblioteki, Prawo i przepisy). Grupa ta wyszczególniona została dodatkowo, w ogromnej większości bowiem nie zawiera misji czy wizji jako odrębnego dokumentu, pośrednią informację uzyskujemy tutaj z bibliotecznych regulaminów, bądź innych dokumentów o normatywnym charakterze.

Rozkłady procentowe w przełożeniu na cztery wyszczególnione i opisane wyżej komponenty prezentuje tab. 4. Poszukiwany element mógł pojawić się zarówno w każdym z wyodrębnionych komponentów (O bibliotece, Informator, Użytkownicy, Regulaminy), w żadnym z nich lub we wszystkich wariantach mieszczących się pomiędzy tymi skrajnymi wskazaniami (na przykład O bibliotece, Regulaminy) - zatem możliwe było więcej niż jedno wystąpienie lub wskazanie. Widać, że zarówno w przełożeniu na procent od liczby bibliotek, jak i ten obliczany od liczby wskazań, najczęściej misja i wizja znajdowały się w zakładce Regulaminy (63\% i 42\%). Pamiętać jednak trzeba, że najczęściej nie możemy mówić tu (jak zaznaczono wyżej) o odrębnych dokumentach, lecz o elementach misji czy wizji zawartych właśnie w regulaminach bibliotecznych. Uwzględniając powyższy warunek, najczęstszym komponentem, w którym biblioteki umieszczały interesujący autorów element, była zakładka O bibliotece (odpowiednio 58\% i 42\%). 
Tabela 4

Komponenty stron WWW bibliotek zawierające link do ich misji/wizji

\begin{tabular}{|c|c|c|}
\hline Komponenty & $\begin{array}{c}\text { Procent od liczby } \\
\text { bibliotek }\end{array}$ & $\begin{array}{c}\text { Procent od liczby } \\
\text { wskazań }\end{array}$ \\
\hline O Bibliotece & 58 & 42 \\
\hline Informator & 12 & 9 \\
\hline Użytkownicy & 5 & 4 \\
\hline Regulaminy & 63 & 46 \\
\hline
\end{tabular}

Źródło: opracowanie własne (n=59).

Rozlokowując te dane na poszczególne typy uczelni (tab. 5) widać, że pomijając w tym miejscu Regulaminy, to biblioteki uczelni ekonomicznych (80\%) najczęściej decydowały się umieszczać swoją misję w zakładce O Bibliotece, najrzadziej zaś biblioteki uczelni o profilu pedagogicznym (z wyłączaniem jednej uczelni teologicznej). Warto też odnotować, że inaczej niż w ogólnym zestawieniu, gdzie komponent Informator występował rzadko - 12\% (tab. 4), w przypadku bibliotek uczelni pedagogicznych znalazł się aż w $40 \%$ przypadków (tab. 5 ).

Tabela 5

Komponenty stron WWW bibliotek zawierające link do ich misji/wizji w rozkładzie według typu uczelni

\begin{tabular}{|c|c|c|c|c|c|c|c|}
\hline 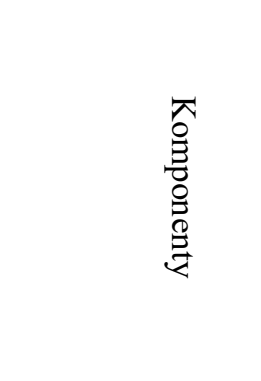 & 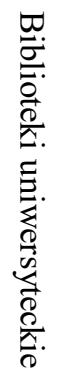 & 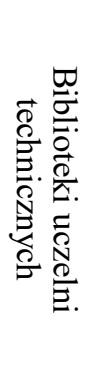 & 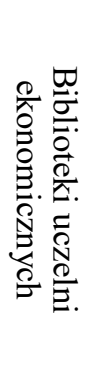 & 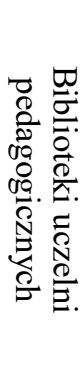 & 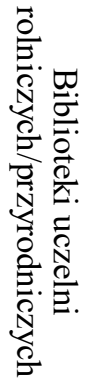 & 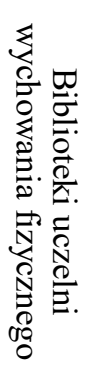 & 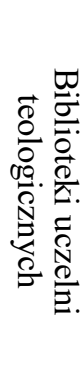 \\
\hline O Bibliotece (\%) & 67 & 44 & 80 & 40 & 67 & 67 & 0 \\
\hline Informator (\%) & 17 & 6 & 0 & 40 & 17 & 0 & 0 \\
\hline Użytkownicy (\%) & 6 & 11 & 0 & 0 & 0 & 0 & 0 \\
\hline Regulaminy (\%) & 67 & 61 & 80 & 80 & 50 & 33 & 100 \\
\hline
\end{tabular}

Źródło: opracowanie własne (n=59). 


\section{Podsumowanie}

Badanie pokazuje, że mniej niż połowa objętych kwerendą bibliotek polskich uczelni akademickich decyduje się na komunikowanie swojej misji użytkownikom odwiedzającym ich strony WWW. Ogromna większość (97\%) bibliotek nie umieszcza żadnego opisu swojej misji czy wizji na stronie głównej, lecz decyduje się włączyć badane elementy w obręb jakiejś większej części strony. Najczęściej jest to zakładka, która niejako programowo zawiera najważniejsze informacje o bibliotece, jej zbiorach, działalności. Znajdujące się na stronach WWW informacje związane z misją i wizją bibliotek ograniczają się jedynie do zapisów w regulaminie poświęconych celom i zadaniom placówki, których jednak nie można traktować tak samo, jak odrębnego tekstu - dokumentu poświęconego tylko i wyłącznie misji czy wizji.

Podsumowując wyniki analizy w kontekście wytyczonego tematu oraz problemu badawczego, można konkludować, że bibliotekarze akademiccy - częstokroć mając świadomość zachodzących w otoczeniu zmian i tego, że bez wyraźnych działań i inicjatyw prowadzić one mogą w kierunku niepewnej przyszłości - zdają się doceniać potencjał tkwiący w dokumentach misyjnych. Jednocześnie, nawet jeśli takowe są tworzone i dostępne w placówce, wciąż niewiele bibliotek uczelnianych decyduje się na ich publikację na swojej stronie WWW. Możliwości informacyjne, promocyjne, jak i inspiracyjne kryjące się w krótkich i chwytliwych hasłach misyjnych, werbalizacjach śmiałych wizji, czy określeniu kluczowych wartości, które z powodzeniem dałoby się umieścić na bibliotecznych portalach internetowych, są (jak widać w analizowanej grupie) praktycznie niewykorzystane. Bibliotekarze „nie powinni zakładać, że interesariusze mają świadomość pełnego zakresu celów biblioteki w XXI wieku"19. Dbając o własny wizerunek, również ten sieciowy, umożliwiając użytkownikom dostęp do dokumentów misyjnych i im podobnych (także poprzez portal WWW) zwiększamy prawdopodobieństwo sprostania różnym i nowym potrzebom naszych czytelników. W czasach ciągłych zmian, konkurencyjności Internetu jako źródła informacji, biblioteki uczelniane powinny zatem z większą uwagą korzystać z szansy komunikacyjnej i promocyjnej, jaką daje ich witryna i bardziej zadbać o to, by zawarte na niej informacje nie budziły wątpliwości użytkowników, co do tożsamości, raison d'être biblioteki i jej planów na przyszłość. Być może w ten właśnie sposób uda nam się przegonić chmury.

\footnotetext{
${ }^{19}$ P. Salisbury, M.R. Griffis, op. cit., s. 596.
} 


\section{Bibliografia}

Bielski M., Organizacje: istota, struktury, procesy, Łódź 2001.

Chełpa S., Zarządzanie wartościami: wizja - misja - kultura - strategia organizacyjna, „Zarządzanie i Marketing. Prace Naukowe Akademii Ekonomicznej we Wrocławiu" 1998, nr 789, s.186-195.

Derfert-Wolf L., Strategia rozwoju biblioteki, [w:] EBIB Elektroniczny Biuletyn Informacyjny Bibliotekarzy. Materiaty konferencyjne, http://www.ebib.pl/publikacje/ matkonf/atr/indexpl.html, [dostęp: 9.04.2017].

Gębołyś Z., Misja biblioteki naukowej w teorii i praktyce, [w:] Zarządzanie strategiczne i marketingowe w bibliotekach, Poznań 2004, s. 43-50.

Karwasiński P., Misja biblioteki: wyzwanie - cel - zadanie. Próba stworzenia misji Biblioteki Uniwersyteckiej w Poznaniu, „Biblioteka” 2006, nr 10 (19), s. 129-144.

Kotler P., Marketing, Poznań 2005.

Kozyra B., Strategiczne zarzadzanie firma - Misja $i$ Wizja, czyli nazywanie marzeń, http://www.przepisnabiznes.pl/dzialalnosc-gospodarcza/strategiczne-zarzadzaniefirma.html, [dostęp: 09.04.2017].

Kuchi T., Communicating Mission: An Analysis of Academic Library Web Sites, „Journal of Academic Librarianship” 2006, vol. 32, no 2, s. 148-154, http:// www.sciencedirect.com/science/article/piiS0099133305001837, [dostęp: 9.04 . 2017].

Le B.P., Academic library leadership in the digital age, „Library Management” 2015, vol. 36, issue 4/5, s. 300-314, http://www.emeraldinsight.com/doi/full/10.1108/ LM-07-2014-0083, [dostęp: 09.04.2017].

McGillis L., The lights are on but nobody's home: the future of academic libraries?, „Partnership: The Canadian Journal of Library and Information Practice and Research" 2016, vol. 11, no 1, s. 1-5, https://journal.lib.uoguelph.ca/index.php/perj/ article/view/3657/3755\#.WOoBU_mLTIV, [dostęp: 09.04.2017].

Meier J.J., The Future of Academic Libraries: Conversations with Today's Leaders about Tomorrow, „Portal: Libraries and the Academy” 2016, vol. 16, no 2, s. 263 -288, http://search.proquest.com/docview/1784465065/fulltextPDFA711FB8C4 0A84B2CPQ/1?accountid=14686, [dostęp: 09.04.2017].

Milewska P., Jak odstraszyć czytelnika, czyli strony internetowe bibliotek, „Biuletyn EBIB" 2015, nr 3 (157a), http://open.ebib.pl/ojs/index.php/ebib/article/viewFile /343/508, [dostęp: 9.04.2017].

Milewska P., Strona $W W W$ biblioteki uczelnianej - kreatywna wizytówka instytucji?, [w:] Kreatywność i innowacje w bibliotece naukowej, red. A. Marciniak, I. Sujkowska, Łódź 2013, s. 105-136, http://cybra.p.lodz.pl/dlibra/docmetadata?id=78 $10 \&$ from $=$ pubindex \&dirids $=1 \& 1 \mathrm{p}=3201$, [dostęp: 05.04.2017].

Salisbury P., Griffis M.R., Academic Library Mission Statements, Web Sites, and Communicating Purpose, „The Journal of Academic Librarianship” 2014, vol. 40, issue 6, s. 592-596, http:/www.sciencedirect.com/science/article/pii/ S0099133314001839?, [dostęp: 9.04.2017]. 
Stover M., Library Web Sites: Mission and Function in the Networked Organization, „Computers in Libraries” 1997, vol. 17, no 10, s. 55-57, http://scholarworks.cals tate.edu/bitstream/handle/10211.2/1704/StoverMark199712.pdf?sequence=1, [dostęp: 9.04.2017].

Wałek A., Strony $w w w$ bibliotek jako element promocji $i$ narzędzie komunikacji z użytkownikiem, „Fides. Biuletyn Bibliotek Kościelnych” 2014, nr 1 (38), s. 109-118, http://www.fides.org.pl/pdf/biuletyn/38_109-118.pdf, [dostęp: 9.04. 2017].

Wojciechowski J., Marketing w bibliotece, Warszawa 1993.

Wojciechowski J., Organizacja i zarządzanie w bibliotekach, Kraków 1998.

Wykaz uczelni publicznych nadzorowanych przez Ministra właściwego ds. szkolnictwa wyższego - publiczne uczelnie akademickie, http://www.nauka.gov.pl/uczelniepubliczne/wykaz-uczelni-publicznych-nadzorowanych-przez-ministra-wlasciwe go-ds-szkolnictwa-wyzszego-publiczne-uczelnie-akademickie.html, [dostęp: 04.04.2017]. 